\title{
LEASING AS EFFECTIVE INTERACTION MECHANISMS BETWEEN GOVERNMENT AND PRIVATE BUSINESS IN THE FIELD OF ROAD INFRASTRUCTURE IN RUSSIA
}

\author{
Komissarova V.V., Lecturer \\ Vladivostok State University of Economics and Service, Vladivostok, Russia \\ E-mail: valeriya.komissarova@vvsu.ru
}

\begin{abstract}
Subject of the article is devoted to the development of cooperation between government agencies and business according to the principles of public-private partnership. Today one of the most important conditions for optimizing the federal budget is the introduction of effective scientific developments in the road sector. For the past several years the problem is posed to achieve not only sufficient amount, but also to improve financing and management mechanisms in the road sector. The experience of developed and developing countries has shown that the impossibility of such industries as a road and utilities, rail and pipeline transport, electricity, ports, airports privatization by virtue of their strategic, social and sociopolitical significance and lack of funds in state budgets for future development formed the basis for creating and implementing the concept of public-private partnership in business practices. Applying of leasing as one of the PPP forms is regarded as the most favorable way of national economy development in Russia. Despite the growing interest of scientists in this issue, many problems have been identified, but not resolved. The issues connected with the formation of systemic notions about the essence, functional and procedural content of publicprivate partnership, the principles and mechanism of its organization, as well as the prospects for development require detailed elaboration.
\end{abstract}

\section{KEY WORDS}

Public-private partnership, roads, transport infrastructure, innovation, concessions, leasing, credit.

Roads constitute the most extensive part of the transport infrastructure. This performs a variety of tasks from the maintenance of international and interregional traffic to ensure entrance to facilities, enterprises, institutions, to the citizens' homes. A significant part of small and medium-sized businesses, which primarily transport small quantities of products or operate in the service sector, tend to use motor vehicles. According to the Federal statistical observation, the public road network in the Russian Federation as of January 1, 2016 has a total length of $1,479.9$ thousand $\mathrm{km}$, of which 51.9 thousand $\mathrm{km}$ are federal roads, 515.8 thousand $\mathrm{km}$ are regional roads, 912.2 thousand $\mathrm{km}$ are local roads. The fact that $36.4 \%$ of the length of highways of federal significance, $61.9 \%$ of the total length of regional highways and $44.8 \%$ of the length of highways of local significance do not meet the regulatory requirements [1].

Analyzing the experience of developed and rapidly developing countries, the changes can be traced in such industries as road and utilities, rail and pipeline transport, electricity, ports, airports, previously completely state-owned and evaluated as a cardinal. The reason for these changes is, on the one hand, the fact that a lack of funds was appeared in the state budgets not only for further development, but also for simple maintenance of effective functioning of these industries and, on the other hand, the impossibility of privatization because of their strategic, social and socio-political significance. This contradiction served as the basis for creating and implementing the concept of public-private partnership (PPP) in business practice.

Various aspects of public-private partnerships formation and functioning are reflected in the research of such scientists as V.G. Varnavsky, V.A. Kabashkin, A.V. Belitskaya, R.M. Japaridze, V.V. Maksimov, , A.A. Alpatov, A.V. Klimenko, A.A. Pushkin, A. Smith, M.I. TuganBaranovsky, Chonka, D. Amunts and others. 
Smith $A$. in his works pointed out that the state should "create and maintain some public enterprises that can never be created by an individual or a group, because profits will never cover costs» [2].The first time projects based on private public partnership (private partnership projects) were implemented in England in the early nineties. It is in the early nineties in England a special law was passed that allowed investors to build the infrastructural facilities with the state on equal footing. Since then, similar laws have started to operate in 40 countries.

Abroad, public-private partnership includes the very wide range of business models and relationships. In the most general sense, the term is applied in any use of private sector resources to meet social needs. Spheres of application of public-private partnerships in foreign countries are very varied. Collaboration between partners can be held in the various legislative bodies, with a diverse range of tasks and competencies.

An international practice of partnership creation shows that they can be implemented in a variety of industries:

Transport - construction, operation, maintenance, traffic management systems implementation and many other projects in various sectors of transport, including urban transport.

Housing and communal services - public services, maintenance of utilities (water, sewerage); street cleaning, removal and disposal of garbage.

Ecology - the creation, maintenance and development of urban and suburban parks with the right of exploitation of natural resources and revenues from the organization of ecotourism.

Real estate - construction and maintenance of public buildings and municipal housing in exchange for the right of development and participation in commercial projects.

Public order and safety - ensuring order in transportation and in public places served by private companies, organization and maintenance of parking lots.

Telecommunications - creation of telecom infrastructure and services for consumers.

Financial sector - involvement of private insurance and asset management companies in the sphere of compulsory social insurance and public pensions.

Education - construction and equipping of schools and other institutions by the private companies that received the right to build and develop adjacent territories [3].

Forms, which public-private partnerships is implemented in have different levels of responsibility of state or the private sector takes over the operation and maintenance, capital investment and ongoing funding, commercial risk, as well as those who own assets and lasting cooperation. The main forms of partnerships are: service contracts, management contracts, leasing, contracts for the construction, operation and transfer (BOT) and their variants; concession. In practice, combinations of these forms are used in foreign countries commonly.

World leaders in the field of public-private partnership the United States and Great Britain, France, Germany are recognized.

To date, the PPP, on the one hand, is regarded as a form of indirect privatization. This is associated with the transfer of broad powers relating to the ownership, operation, construction and financing facilities (the experience of developed countries) by state to private business. On the other hand, PPP is as alternative to privatization, which allows to realize the potential of private capital and retain control functions of the state in significant public sectors of economy that are strategically important.

The main common features defining PPP are: firstly, the purpose of PPP is the realization of both national and international social projects in various fields in the interaction of state and business structures in the long term and, second, the principle of public-private partnership is based on pooling resources and sharing risks between the parties [4].

Using the mechanisms of public-private partnership (PPP) is widely spreading in the Russian Federation now.

Despite the fact that today in Russia, public-private partnership, from a legal point of view, can only be exercised on the basis of the law on concessions, this kind of partnership may act in such forms as governmental contracts, rent, financial rent (leasing), public-private 
ventures, production sharing agreements and concession agreements [3].

PPP includes a number cooperation forms, allowing the state and the private sector to derive mutual benefit, referring to the innovative methods used by the public sector to contract with the private sector, that use their own capital and management capacity in implementing projects in accordance with established timeframes and budgets. The public sector retains the responsibility for the provision of these services by profitable way and has a positive impact on economic development and improvement life's quality.

PPP is regarded like the specific projects being implemented by public authorities and private companies for objects of federal, regional and municipal property jointly.

During the years of reform, Russia's economy has undergone a series of structural reforms that resulted in a reduction of the public sector and transfer of management functions in critical infrastructure in the hands of private business. Under the circumstances, it is essential to move to a strategic partnership with the private sector, to create such system of relations that would provide a rational combination of free competition and measures of state regulation in order to serve the public interest.

In this regard, the attention is increasingly focused on public-private partnership as one of the most important mechanisms to attract private capital for the solving of socio-economic problems in Russia. Such an alliance is advantageous for private companies because of a simple reason - to receive the income from investments, and the state - because of budget savings during the implementation of socially significant investment projects [5].

Leasing, which is a procedure of borrowing in the form of long-term loan provided in natural form and repaid in installments, has established itself as an effective mechanism for attracting investment in road construction and service sectors of road facilities, utilities and passenger traffic [6].

As a vivid example of the collaboration of businesses and government the creation of aviation leasing company «llyushin Finance Co» can be demonstrated, a company that for several years has created a portfolio of orders for billions of dollars, thus creating a favorable environment for the development of the national aircraft industry, and the money invested by the state in this project, returned to the budget in taxes.

Now, as a few years ago, leasing is a very promising direction. Analysts have found several reasons for the rapid development of the leasing of construction and road machinery in Russia. The most important reason is increasing the volume of construction - average annual growth rate is $10-15 \%$. High deprecation rate of available technology plays a significant role of in enterprises. Due to the fact that the development of construction is still going on, in the coming years high rates growth can be observed in the leasing market [7].

Today, a significant portion of all leasing deals in Russia are deals on road transport, railway transport, road construction equipment, aircraft equipment, power equipment, as well as equipment designed for the extraction of minerals (is presented in Figure 1).

Issues of the road network development are currently among the top priority for Russia. Creating a modern road transport network is one of the factors ensuring steady economic growth, execution of social programs and improving the quality of life. Transportation is an industry where various forms of public-private partnership have to be successfully implemented, as it is considered as one of the most important sectors that can enhance the competitiveness of the Russian economy.

The choice of public-private partnership in road construction is determined by two factors: transport is not an end in itself but a mean for implementing economic activities and social life. In this sense, the majority of transportation projects are of great socio-economic value that does not cause a large interest among potential investors; transport infrastructure is the capital-intensive industry, so funding for the initial phase results in a fairly significant amount.

Today, park equipment of road sector is characterized by high deprecation and a relatively small amount of modern machinery and equipment that can provide qualitative indicators of construction, repair and maintenance of roads, which depend on the technical level of most equipment and its degree of automation. 


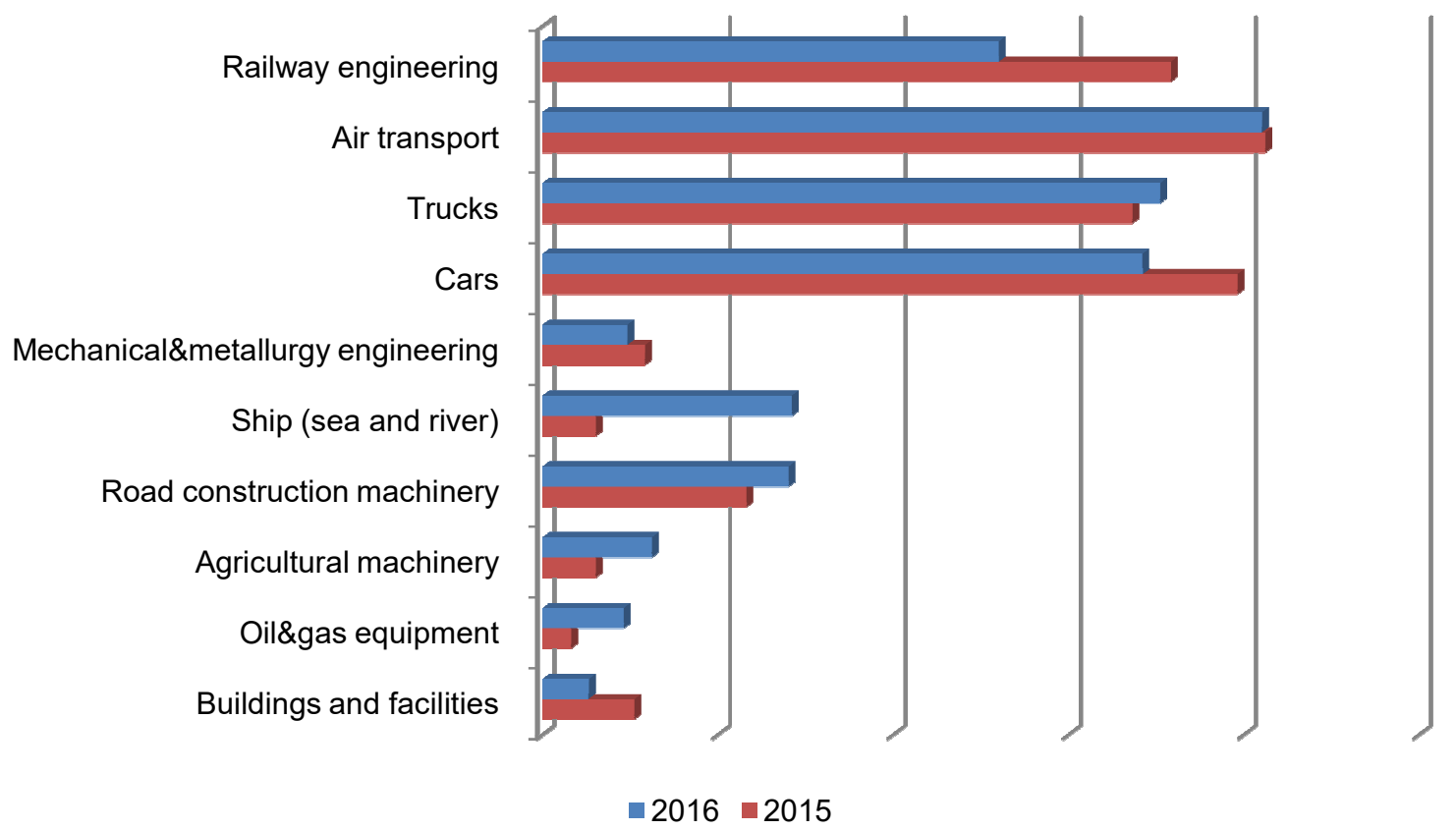

Figure 1 - Key market segments share in the new business [8] Source: compiled by the author according to «Expert RA»

Given the size of the country and, consequently, the necessity for construction and repair of roads, the development of industry and quality assurance of roadworks issues require a new approach in investing with the purpose of technical re-equipment of the road sector. Use of public-private partnership in the road sector can be seen from the viewpoint of innovation, which can provide budget savings at the various stages of road works by reducing the cost of the works themselves, increasing the maintenance period, bringing the technical capacity of the industry to a level that meets the needs of the country in freight and passenger transportation.

The use of leasing as a form of public-private partnership is one of the most appropriate instruments to attract investment in the road sector [7].

For road businesses attractiveness of leasing arrangements can be explained by the fact that the acquisition of machinery and equipment reduces the need for proper start-up capital - it means that lump sum is not required to pay for necessary equipment that frees up user's liquidity, increases the working capital to expand production without drastic financial stress allows to update the fixed assets.

The advantages of purchasing equipment under leasing contracts are:

1. Assignment of lease payments at the cost of production and jobs that reduces the tax base (income tax).

2. The use of accelerated depreciation, which increases the possibility of rapid updating of obsolete equipment and technical upgrading of production. The period of the lease agreement is much less than the statutory age of the property and the customer does not pay full property tax due to accelerated depreciation.

3. The amount of VAT on the lease agreement in its entirety is placed to offset.

4. The flexibility of lease payments is provided by: the grace period is possible, a gradual increase or decrease benefits, orientation for seasonal work that is important enough for the road sector enterprises.

5. Leasing contracts are cheaper than credit.

6. The risk for the development of innovative products is insignificant: in case of insufficient demand there is an opportunity to return the property to lessor [9].

To substantiate the benefits of leasing schemes represent a simple comparative analysis of the acquisition of road equipment by credit or leasing. 
The structure of lease payments compensation is included for the property tax of leasing company in the project framework taking into account accelerated depreciation for the period of the lease agreement. Advanced payment on a lease agreement is not provided.

Table 1 - Comparison of costs of the enterprise acquiring equipment through the credits in commercial bank and leasing scheme

\begin{tabular}{|c|c|c|}
\hline 1 & The cost of the equipment including VAT, rub. & 5000000 \\
\hline 2 & Advanced payment & $0 \%$ \\
\hline 3 & The amount of down payment, VAT included, rub. & - \\
\hline 4 & Transportation tax, registration with the traffic police and customs fees (if applicable), rub. & - \\
\hline \multicolumn{3}{|c|}{ CREDIT SCHEME } \\
\hline 5 & Loan amount, rub. $(1-3+4)$ & 5000000 \\
\hline 6 & The term of the loan, months. & 36 \\
\hline 7 & Interest on bank loan, \% & 16 \\
\hline 8 & Accrued interest (accruing on the balance), rub. & 1233485,54 \\
\hline 9 & Total: $(5+8)$ & 6233485,54 \\
\hline 10 & VAT to offset (purchase of equipment), rub. & 762711,86 \\
\hline 11 & The tax on assets of the company, rub. & 244882,66 \\
\hline 12 & Accumulated depreciation during the period (excluding accelerated depreciation), rub. & 1271186,44 \\
\hline 13 & The amount of reduction of the tax base for income tax, rub. $(8+11+12)$ & 2749554,64 \\
\hline 14 & Income tax saving, now. $(13 \times 0.24)$ & 659893,11 \\
\hline 15 & The amount that reduces the costs of the company on taxes, rub. $(10+14)$ & 1422604,97 \\
\hline 16 & Total cost of the enterprise under a credit scheme, rub. $(3+9+11-15)$ & 5055763,23 \\
\hline \multicolumn{3}{|c|}{ LEASING SCHEME } \\
\hline 17 & The sum of all payments under the lease agreement, rub. & 7257299,85 \\
\hline 18 & VAT to offset (amounts of the lease payments), rub. & 1107045,74 \\
\hline 19 & The amount of reduction of the tax base for income tax, rub. $(17-18)$ & 6150254,11 \\
\hline 20 & Income tax savings, rub. $(19 \times 0.24)$ & 1476060,99 \\
\hline 21 & The amount that reduces the costs of the company on taxes, rub. $(18+20)$ & 2583106,73 \\
\hline 22 & Total costs for the company leasing scheme, rub. $(17-21)$ & 4674193,12 \\
\hline 23 & $\begin{array}{l}\text { Leasing scheme savings, rub. }(16-22) \\
\text { Leasing scheme savings in } \% \\
\text { Rate loan, giving the same effect }\end{array}$ & $\begin{array}{c}381570,11 \\
7,631 \% \\
7,75 \%\end{array}$ \\
\hline
\end{tabular}

These calculations reflect the following costs of the enterprise.

Credit (study period - 3 years):

- Repayment of the loan principal: 5000000 rubles.

- Accrued interest: 1233 485, 54 rubles.

- Tax on enterprise property during the analyzed period: 244882,66 rubles.

- During the study period, the amount of accumulated depreciation will be: 1271 186,44 rubles.

So, we see, that accrued interest on the loan, accrued property tax on businesses and accumulated depreciation for the equipment is deductible for income tax and is as follows: 2 749554,64 rubles. Thus, income tax savings will be 659893,11 rubles, and in the amount of VAT is equal to 762711,86 rubles, formed with the purchase of equipment, gives the enterprise tax savings in the amount of 1422604,97 rubles.

Costs of the company under a credit scheme is the sum of the advance payment from its own resources (in our example 0), the amount of the loan principal and accrued interest of the loan life period, the property tax business during the analyzed period, less the value of saving the company taxes. The credit scheme cost will be 5055763,23 rubles.

Leasing:

The total amount of lease payments during the lease agreement term on a standard calculation is 7257299,85 rubles. Due to the fact that the accrual of the total lease payments of VAT equal to 1107045,74 rubles, the company aims to offset, the amount of reduction of the tax base for income tax will be 6150254,11 rubles.

Thus, income tax savings will be 1476060,99 rubles, and in the amount of charging VAT on the full amount of lease payments, provides cost savings for the company tax rate in sum of 2583106,73 rubles. 
Costs of the leasing scheme are the sum of all lease payments for the term of the lease agreement minus the value company's taxes savings. Leasing scheme costs will be 4674 193, 12 rubles.

It's clear, that the difference in real spending in the enterprise of leasing and loan company provides cost savings when leasing scheme at a rate of 381570,11 rubles, which amounts to $7,631 \%$ of the purchase price of equipment.

To draw an analogy to a bank loan, the cost of enterprise leasing scheme provided the acquisition of fixed assets would be similar costs for bank credit, which was taken at a rate of $7,75 \%$ per annum.

Conclusion. Advantages of using forms of PPP are obvious, so Russian government need to accelerate the creation of a legal framework for the wider use of leasing and other forms of public-private partnership in which the partnership with the private sector can bring greater benefits through effective quality of service, while at the same time, let the legislative authorities allocation of rights, responsibilities and risks between the state and investors in the implementation of various transportation projects.

Public-private partnership has become one of the main instruments of government management in the world. Events of the past fifteen years clearly showed that, for addressing the complex socio-economic, structural, and technological and other strategic development objectives of Russia for realizing its national interests and providing a supportive living environment, there is a need do exist for integration of private enterprise economic potential and the capabilities of the state.

\section{REFERENCES}

1. Information and analytical materials for the meeting of the Public Council under the Ministry of Transport of the Russian Federation on the issue «The state and prospects of the public net-work roads development» [Electronic resource] / Ministry of Transport of the Russian Federation, 2010.

2. Smith A. Research on the nature and causes of the nation's wealth. - M.-L., 1935 - P.32

3. Amunts D.M. «Public-private partnerships. The concession model in the joint participation of public and private sector in implementing financial sector-capacity projects» / / Directory cultural institution. - 2005. - №12.

4. Chonka A. «Public-private partnership: the symbiosis of government and business» [Electronic resource] / Law Portal «Akron», 2010. - Mode of access: http://arkongroup.ru/see.php?see $=56$

5. Varnavsky V.G., Klimenko A.V. Public-private partnership: theory and practice // State University - Higher School of Economics. - Moscow: University of Higher School of Economics, 2010. - p. 119-125

6. Alpatov A.A. et al. Public-Private Partnership: Implementation Mechanisms // LLC "Alpina", 2011. - Mode of access: http://thelib.ru/books/a_v_pushkin/

7. "About strengthening of the tenants' influence on the development of leasing construction machinery in Russia» [Electronic resource] / Portal on the special road and construction equipment «ADC Engineering», 2011. - Mode of access: http://www.adctehnika.ru/content/review/4145/Lizing-vzyalsya-za-novoe/

8. R. Romanovsky «The leasing market for the 2016» [Electronic resource] / Rating agency Expert RA, 2016. - Mode of access: https://raexpert.ru/researches/leasing/2016/part1

9. Moskvin "Leasing - the best way to update the fixed assets» [Electronic resource] / Online magazine «Fixed assets», 2006. - Mode of access: http://www.os1.ru/article/business/2006_06_A_2006_11_03-17_47_43/ 